\title{
DAMPAK PSIKOLOGI PANDEMI CORONA VIRUS DISEASE 2019 (COVID-19) BAGI MASYARAKAT DI KELURAHAN PELELOAN KECAMATAN TONDANO SELATAN KABUPATEN MINAHASA
}

\author{
Charisma B.J. Pesik ${ }^{1}$, Hendro Bidjuni $^{2}$, Kristamuliana $^{3 *}$ \\ ${ }^{a}$ Charisma B.J.Pesik (Mahasiswi PSIK FK Unsrat, Indonesia) \\ ${ }^{b}$ Hendro Bidjuni (Dosen PSIK FK Unsrat, Indonesia) \\ ${ }^{c}$ Kristamuliana (Dosen PSIK FK Unsrat, Indonesia) \\ *Email : charismabrendajeniferpesik@gmail.com
}

\begin{abstract}
:
Background of this journal is The Covid-19 pandemic health crisis causes psychological changes such as fear, anxiety, depression, or insecurity. Aim of this study was to determine the psychological impact of the Covid-19 pandemic on the community in Peleloan Village, South Tondano District, Minahasa Regency. Methods of this study used descriptive research/survey with samples, this research involved 317 respondents obtained by using the random sampling, and using the questionnaire research instrument Depression Anxiety Stress Scales (DASS 42). Results of the study show that there was a psychological impact of the Covid-19 pandemic for the community with the result that there were 14 respondents (4.4\%), with a normal stress level of 199 respondents (62.8\%), normal anxiety levels of 127 respondents (40.1\%), and normal depression levels were 201 respondents (63.4\%). Conclusion, Most people do not experience stress, most people do not experience anxiety, and most people do not experience depression. The implications of this research can be useful for the public to know the impact of Covid-19 and for the health workers, when you know the impact of Covid-19, it will be easy to carry out prevention of the emergence of these psychological impacts.
\end{abstract}

Key Words: Corona Virus Disease 2019; Depression; Psychological Impact of Pandemic; Anxiety; Stress

\begin{abstract}
Abstrak:
Latar Belakang dari jurnal ini adalah Krisis kesehatan pandemi Covid-19 menyebabkan perubahan psikologis seperti ketakutan, kecemasan, depresi, atau ketidakamanan. Tujuan penelitian ini adalah untuk mengetahui dampak psikologis pandemi Covid-19 bagi masyarakat di Kelurahan Peleloan Kecamatan Tondano Selatan Kabupaten Minahasa. Metode penelitian menggunakan penelitian deskriptif/survei dengan Sampel berjumlah 317 responden yang diperoleh melalui random sampling, dan menggunakan instrument penelitian Kuesioner Depression Anxiety Stress Scales (DASS 42). Hasil penelitian menunjukan bahwa ada dampak psikologis pandemi Covid-19 bagi masyarakat dengan hasil terdapat kasus Covid-19 14 responden (4.4\%), terdapat tingkat stress normal sebanyak 199 responden (62.8\%), tingkat kecemasan normal sebanyak 127 responden (40.1\%), dan tingkat depresi normal sebanyak 201 responden (63.4\%). Kesimpulan, Sebagian besar masyarakat tidak mengalami stress, sebagian besar masyarakat tidak mengalami kecemasan, dan sebagian besar masyarakat tidak mengalami depresi. Implikasi dari penelitian dapat bermanfaat bagi masyarakat untuk mengetahui dampak akibat dari Covid-19 dan bagi tenaga kesehatan, ketika telah mengetahui dampak dari covid-19 maka akan mudah untuk melaksanakan pencegahan terhadap munculnya dampak psikologis tersebut.
\end{abstract}

Kata Kunci : Coronavirus Disease 2019; Depresi; Dampak Psikologi Pandemi; Kecemasan; Stres 


\section{PENDAHULUAN}

Data Organisasi Kesehatan Dunia (WHO), Covid-19 ialah penyakit yang disebabkan oleh virus SARS CoV-2 yang terus muncul dan menjadi masalah serius bagi kesehatan masyarakat. Dalam dua puluh tahun terakhir, epidemi virus seperti Severe Acute Respiratory Syndrome coronavirus (SARS-CoV) pada tahun 2002-2003, dan influenza H1N1 pada 2009. Kemudian, Middle East Respiratory Syndrome Coronavirus (MERS-CoV) pertama kali diidentifikasi di Arab Saudi pada tahun 2012. Terbaru adalah kasus epidemi dengan infeksi pernapasan terjadi di Wuhan, daerah metropolitan terbesar di Provinsi Hubei Cina, pertama kali dilaporkan ke WHO, pada 31 Desember 2019. Karena tidak dapat mengidentifikasi agen penyebab, kasus pertama diklasifikasikan sebagai "pneumonia dengan etiologi yang tidak diketahui." Pusat Pengendalian dan Pencegahan Penyakit (CDC: Chinese Disease Control and Prevention) menyelenggarakan program investigasi wabah yang intensif. Etiologi penyakit tersebut dihubungkan dengan virus baru milik keluarga corona virus (WHO, 2020).

Pada 11 Februari 2020, Direktur Jenderal WHO, Dr. Tedros Adhanom Ghebreyesus, mengumumkan bahwa penyakit yang disebabkan oleh $\mathrm{CoV}$ baru ini adalah "Covid-19," yang merupakan singkatan dari "penyakit coronavirus 2019". Dalam dua puluh tahun terakhir, dua epidemi CoVs telah terjadi. SARS$\mathrm{CoV}$ memicu epidemi skala besar dimulai di Tiongkok, melibatkan 24 negara dengan 8000 kasus dan 800 kematian, kemudian MERS-CoV yang dimulai di Indonesia sendiri, sesaat setelah pengumuman 2 orang pertama yang positif terinfeksi COVID-19 pada 2 Maret 2020, beberapa stok barang seperti makanan pokok, hand sanitizer, hingga masker habis diserbu oleh masyarakat di Jakarta (Satgas Covid, 2020).

Data pada tanggal 06 Januari 2021, Satuan Gugus Tugas Provinsi Sulawesi
Utara melaporkan sampai saat ini angka kejadian kasus konfirmasi positif Covid-19 berjumlah 10.155 yang diberbagai daerah di Sulawesi Utara dengan akumulasinya kasus yang dirawat sebanyak 2.339 orang, kasus sembuh sebanyak 7.490 dan kasus meninggal sebanyak 326. Kasus dengan Suspek atau Orang dengan gejala ISPA atau Covid-19 dan pada 14 hari terakhir memiliki riwayat perjalanan, tinggal di negara/wilayah yang melaporkan transmisi lokal, atau riwayat kontak dengan kasus konfirmasi/probable Covid-19 yang diisolasi sebanyak 276 kasus dengan kasus negatif 22 kasus. Kasus dengan Probable atau Orang yang diyakini sebagai suspek dengan ISPA Berat atau gagal nafas atau meninggal dengan gambaran klinis Covid19 dan hasil laboratorium RT-PCR belum keluar yang diisolasi sebanyak 10 kasus dan meninggal 3 kasus. Kasus dengan Kontak Erat atau Orang yang memiliki riwayat kontak dengan kasus probable atau konfirmasi Covid-19 sebanyak 6.683 kasus dengan selesai sebanyak 4.863 kasus, (Satgas SULUT,2020). Dengan melonjaknya kasus Covid-19 sehingga berdampak pada psikologis pada warga yang ada di Sulawesi Utara.

Berbagai gangguan psikologis juga telah dilaporkan dan dipublikasi selama wabah Covid-19 di Cina, baik pada tingkat individu, komunitas, nasional, dan internasional. Pada tingkat individu, orang lebih cenderung mengalami takut tertular dan mengalami gejala berat atau sekarat, merasa tidak berdaya, dan menjadi stereotip terhadap orang lain. Pandemi bahkan menyebabkan krisis psikologis. Identifikasi individu pada tahap awal gangguan psikologis membuat strategi intervensi lebih efektif. Krisis kesehatan pandemi Covid-19 menyebabkan perubahan psikologis seperti ketakutan, kecemasan, depresi, atau ketidakamanan. Gangguan ini tidak hanya dirasakan oleh tenaga kesehatan atau semua orang yang bekerja di bidang medis, tetapi juga seluruh warga Negara, (Rina, 2020 dalam Xiang, 2020). 
Perhimpunan Dokter Spesialis Kedokteran Jiwa Indonesia (PDSKJI) melakukan survei mengenai kesehatan mental melalui swaperiksa yang dilakukan secara daring. Pemeriksaan dilakukan terhadap 1.552 responden berkenaan dengan tiga masalah psikologis yaitu cemas, depresi, dan trauma. Responden paling banyak adalah perempuan $(76,1 \%)$ dengan usia minimal 14 tahun dan maksimal 71 tahun. Responden paling banyak berasal dari Jawa Barat 23,4\%, DKI Jakarta 16,9\%, Jawa Tengah $15,5 \%$, dan Jawa Timur 12,8\% (PDSKJI, 2020).

Masyarakat Kelurahan Peleloan Kecamatan Tondano Selatan Kabupaten Minahasa dengan jumlah penduduknya sekitar 1.538 jiwa untuk tetap tinggal dirumah bahkan semua pekerjaan dilakukan dari rumah, sebagian besar masyarakat Kelurahan Peleloan Kecamatan Tondano Selatan Kabupaten Minahasa yang belum mengetahui tentang wabah atau pandemi Covid-19 yang terjadi saat ini. sehingga masih banyaknya tempat umum ataupun fasilitas umum di Kelurahan tersebut yang belum mampu menerapkan adanya protokol kesehatan, yaitu social distancing, mencuci tangan, menggunakan masker dan melakukan etika batuk yang baik dan benar dalam memutus penyebaran Covid-19 di lingkungan sekitar.

\section{METODE}

Penelitian ini menggunakan penelitian deskriptif/survei. Populasi pada penelitian ini ialah seluruh masyarakat di Kelurahan Peleloan Kecamatan Tondano Selatan Kabupaten Minahasa dengan jumlah penduduk 1.538 orang. Pengambilan sampel pada penelitian ini berjumlah 317 responden yang diperoleh melalui random sampling. Instrumen dalam pengumpulan data dan informasi pada responden, peneliti menggunakan pengumpulan data dalam bentuk kuesioner menggunakan instrument penelitian Kuesioner Depression Anxiety Stress Scales (DASS 42), yang dibagikan melalui
WhatsApp yang terdiri dari tingkat stress, tingkat kecemasan, dan tingkat depresi. Pengolahan data yang diperoleh dari hasil penelitian ini diolah secara manual dan dianalisis secara statistik melalui komputerisasi Chi-Square.

Dalam melakukan penelitian, peneliti menggunakan etika penelitian yang terdiri dari Informed consent, Anonymity (tanpa nama), dan Confidentially. Dalam menggunakan etika penelitian, peneliti menjelaskan bahwa telah mendapat persetujuan dari tempat penelitian yaitu Kelurahan Peleloan Kecamatan Tondano Selatan Kabupaten Minahasa dengan Nomor: 06/1006/SK/III/2021. Analisa data dilakukan terhadap variabel penelitian untuk meneliti tampilan distribusi frekuensi dan presentase dari tiap-tiap variabel. Sehingga, menunjukan hasil Sebagian besar masyarakat tidak mengalami stress, sebagian besar masyarakat tidak mengalami kecemasan, dan sebagian besar tidak mengalami depresi. 
Jurnal Keperawatan, Volume 9, No. 2, Agustus 2021, (Hal. 7-15)

\section{HASIL PENELITIAN}

Tabel 1. Karakteristik Responden

\begin{tabular}{llcc}
\hline No & \multicolumn{1}{c}{ Variabel } & $\mathrm{f}$ & $\%$ \\
\hline 1. & Usia & & \\
& - Usia 17-25 Tahun (Masa Remaja Akhir) & 126 & 39.7 \\
& - Usia 26-35 Tahun (Masa Dewasa Awal) & 86 & 27.1 \\
- Usia 36-45 Tahun (Masa Dewasa Akhir) & 53 & 16.7 \\
- Usia 46-55 Tahun (Masa Lansia Awal) & 35 & 11.0 \\
- Usia > 56 Tahun (Masa Lansia Akhir) & 17 & 5.4 \\
2. Pendidikan & & \\
- SD & 5 & 1.6 \\
- SMP & 15 & 4.7 \\
- SMA & 178 & 56.2 \\
- DIII/Sarjana & 119 & 37.5 \\
Pekerjaan & & \\
- Tidak Bekerja & 237 & 74.8 \\
- Bekerja & 80 & 25.2 \\
\hline
\end{tabular}

Karakteristik responden berdasarkan usia, responden terbanyak berada pada usia Masa Remaja Akhir (17-25 tahun)dengan jumlah 126 responden (39.7\%), sedangkan yang paling sedikit berada pada usia Masa Lansia Akhir (> 56 tahun) dengan jumlah 17 responden $(25.4 \%)$.

Karakteristik responden berdasarkan tingkat pendidikan, tingkat pendidikan responden terbanyak berada pada tingkat pendidikan SMA dengan jumlah 178 responden $(56.2 \%)$, sedangkan yang paling sedikit berada pada tingkat pendidikan SD dengan jumlah 5 responden (1.6\%).

Karakteristik responden berdasarkan status pekerjaan, status pekerjaan responden terbanyak berada pada responden tidak bekerja dengan jumlah 237 responden $(74.8 \%)$, sedangkan yang paling sedikit berada pada bekerja dengan jumlah 80 responden(25.2\%).

Tabel 2. Hasil Penelitian

\begin{tabular}{llc}
\hline 1. & Tingkat Stres & \\
- Normal & 199 & 62.8 \\
- Ringan & 52 & 16.4 \\
- Sedang & 38 & 12.0 \\
- Parah & 25 & 7.9 \\
- Sangat Parah & 3 & 0.9 \\
\hline 2. Tingkat Kecemasan & & \\
- Normal & 127 & 40.1 \\
- Ringan & 37 & 11.7 \\
- Sedang & 77 & 24.3 \\
- Parah & 31 & 9.8 \\
- Sangat Parah & 45 & 14.2 \\
\hline Tingkat Depresi & & \\
- Normal & 201 & 63.4 \\
- Ringan & 48 & 15.1 \\
- Sedang & 42 & 13.2 \\
- Parah & 15 & 4.7 \\
- Sangat Parah & 11 & 3.5 \\
\hline
\end{tabular}


Karakteristik responden berdasarkan tingkat stres, tingkat stres responden terbanyak berada pada normal dengan jumlah 199 responden (62.8\%), sedangkan tingkat stress responden yang paling sedikit berada pada tingkat stress sangat parah dengan jumlah 3 responden $(0.9 \%)$.

Karakteristik responden berdasarkan tingkat kecemasan, tingkat kecemasan responden terbanyak berada pada normal dengan jumlah 127 responden (40.1\%), sedangkan tingkat kecemasan responden yang paling sedikit berada pada tingkat kecemasan parah dengan jumlah 31 responden $(9.8 \%)$.

Karakteristik responden berdasarkan tingkat depresi, tingkat depresi responden terbanyak berada pada normal dengan jumlah 201 responden (63.4\%), sedangkan tingkat depresi responden yang paling sedikit berada pada tingkat depresi sangat parah dengan jumlah 11 responden (3.5\%).

\section{PEMBAHASAN}

\section{Tingkat Stres}

Karakteristik

responden

berdasarkan tingkat stres, tingkat stres responden terbanyak berada pada normal dengan jumlah 199 responden (62.8\%), sedangkan tingkat stress responden yang paling sedikit berada pada tingkat stress sangat parah dengan jumlah 3 responden (0.9\%). Hasil penelitian menunjukan bahwa dari 317 responden berdasarkan tingkat stres, tingkat stres responden terbanyak berada pada normal dengan jumlah 199 responden $(62.8 \%)$, sedangkan tingkat stress responden yang paling sedikit berada pada tingkat stress sangat parah dengan jumlah 3 responden $(0.9 \%)$. Saat ini, pandemi Covid-19 menjadi salah satu krisis kesehatan utama bagi setiap individu dari semua bangsa, benua, ras, dan kelompok social ekonomi. Kondisi kesehatan masyarakat terkait penularan Covid-19 dibagi menjadi enam kelompok yaitu orang sehat, orang tanpa gejala, orang dalam pemantauan, pasien dalam pengawasan, orang yang positif Covid-19 (Kemenkes RI, 2020).

Hawari (2016), berpendapat bahwa stres dipengaruhi oleh beberapa faktor yaitu perkawinan, problem orang tua, hubungan interpersonal, pekerjaan, lingkungan hidup, keuangan hukum, perkembangan, penyakit fisik atau cidera, faktor keluarga dan trauma. Asumsi peneliti terkait dengan masalah ini adalah bahwa stress yang dialami oleh warga Kelurahan Peleloan masih dalam batas normal tapi kadang warga merasa takut akan tertular virus covid19 yang bisa membawa infeksi dan menularkannya kepada anggota keluarga mereka, atau orang lain, bahkan bisa diisolasi ketika terinfeksi dan membuat mereka jauh dari keluarga. Gangguan psikologi warga Kelurahan Peleloan lebih dialami oleh laki-laki karena sebagian besar aktivitas atau pekerjaan dibatasi bahkan di PHK dari pekerjaan dan sesuai dengan hasil yang paling didominasi adalah yang tidak kerja yang mengakibatkan pendapatan berkurang demi memenuhi kebutuhan sehari-hari.

\section{Tingkat Kecemasan}

Hasil penelitian menunjukan bahwa dari 317 responden berdasarkan tingkat kecemasan, tingkat kecemasan responden terbanyak berada pada normal dengan jumlah 127 responden (40.1\%), sedangkan tingkat kecemasan responden yang paling sedikit berada pada tingkat kecemasan parah dengan jumlah 31 responden (9.8\%).

Hawari (2011) menyatakan bahwa kecemasan adalah gangguan alam perasaan yang ditandai dengan perasaan ketakutan atau kekhawatiran yang mendalam. Penelitian sejalan dengan 
penelitian Wiwiek, 2020 dari 202 responden di dapatkan hasil bahwa hampir $70 \%$ responden mengalami kecemasan. Kategori kecemasan paling tinggi adalah cemas ringan dengan nilai sebanyak 99 responden $(49,0 \%)$.

Hasil penelitian ini dapat di pengaruhi oleh penelitian yang dilakukan secara online menggunakan google form sehingga mayoritas didominasi usia remaja dan dewasa yang lebih sering mengakses gadget dan internet. Selain itu sesuai dengan studi pendahuluan bahwa warga mengungkapkan lebih takut kehilangan pekerjaan dari pada adanya Covid-19 karena jika tidak bekerja, tidak dapat memenuhi kebutuhanya.

Joharudin, A, dkk, 2020 mengungkapkan bahwa adanya pendemi Covid-19 dapat menyebabkan kecemasan di masyarakat, hal tersebut diakibatkan karena adanya aturan pemerintah yaitu lock down dan PSBB yang diterapkan untuk mengurangi penyebaran, adanya aturan tersebut yang membuat pengguna barang dan jasa atau pelanggan sepi sehingga dapat menimbulkan adanya peningkatan angka pengangguran serta dapat memicu terjadinya kecemasan pada pedagang atau karyawan karena maraknya pelaku usaha menutup usahanya dan melakukan pemutusan hubungan kerja (PHK).

Asumsi peneliti terkait kecemasan pada masyarakat Kelurahan Peleloan masih dalam batas normal dan lebih banyak dialami warga yang berusia masih mudah karan tidak memenuhi keinginannya dalam melakukan aktifitas atau dibatasi. Selain itu pernyataan warga Kelurahan Peleloan merasa kadang merasa cemas juga karena kurangnya ketersediaan alat pelindung diri yang terbatas, bahkan obat virus covid-19 belum ditemukan/belum ada sampai saat ini. Gangguan psikologi yang dialami oleh warga karena mendengar informasi bahwa semua rumah sakit atau pelayanan kesehatan mengcovidkan pasien dan bahkan ketika keluarga pasien meninggal dunia dikuburkan sesuai protap jenazah yang mengakibatkan keluarga tidak bisa melihat ketika jenazah dikuburkan.

\section{Tingkat Depresi}

Hasil penelitian menunjukan bahwa dari 317 responden berdasarkan tingkat depresi, tingkat depresi responden terbanyak berada pada normal dengan jumlah 201 responden (63.4\%), sedangkan tingkat depresi responden yang paling sedikit berada pada tingkat depresi sangat parah dengan jumlah 11 responden $(3.5 \%)$.

Penelitian ini sejalan dengan penelitian yang dilakukan oleh Uswatun, 2020 tentang depresi pada mahasiswa selama masa pandemi Covid-19 didapatkan hasil menunjukkan sebanyak 21,1 \% mahasiswa mengalami depresi ringan, $17 \%$ mahasiswa mengalami depresi sedang dan 3,4\% mengalami depresi berat.

Depresi merupakan masalah kesehatan utama yang menyebabkan penurunan produktivitas dalam studi atau bekerja, kognitif, psikomotor, hilangnya inisiatif, dan apatis (Nagaraja, Reddy, Ravishankar, Jagadisha \& Muninarayana, 2015). Penelitian dilakukan oleh PDSKJI pada kondisi pandemi Covid-19 yang cukup panjang memunculkan beragam masalah kesehatan mental. Berdasarkan data dari 14.619 individu yang mendapatkan penanganan dari psikolog klinis anggota Ikatan Psikolog Klinis Indonesia (IPK-Indonesia), 4 masalah 
yang paling banyak ditemui adalah kesulitan belajar, kecemasan, stress, dan gangguan mood antara lain depresi. Hal ini selaras dengan temuan hasil kuesioner swaperiksa masyarakat yang dilakukan oleh Perhimpunan Dokter Spesialis Kedokteran Jiwa Indonesia (PDSKJI) bahwa $57.6 \%$ yang melakukan swaperiksa teridentifikasi memiliki gejala depresi. Terdapat $58.9 \%$ pasien swaperiksa melaporkan memiliki pikiran kematian dan menyakiti diri sendiri, bahkan $15.4 \%$ di antaranya melaporkan bahwa mereka mengalaminya setiap harinya.

Seseorang yang tidak dapat melakukan aktivitasnya secara normal atau terdapat pembatasan secara sosial, maka dapat mempengaruhi tingkat depresinya (Kupferberg, dkk, 2016). Untuk bisa mengurangi tingkat depresi, cemas dan stress dari masyarakat maka perlu dilakukan sosialisasi kepada masyarakat mengenai layanan psikologis yang tersedia dan edukasi yang masif mengenai Covid-19 supaya masyarakat bisa membedakan antara fakta dengan yang bukan, koordinasi lintas sektoral yang lancar, hingga pelibatan pihak swasta serta masyarakat menjadi kunci berhasilnya implementasi penanganan permasalahan kesehatan mental akibat pandemik Covid-19.

Peneliti terhadap masalah ini adalah bahwa Depresi di kalangan warga Kelurahan Peleloan masih dalam rentan normal. Sekalipun banyak warga yang yang terlihat cemas dengan kondisi yang mereka alami seperti sulit tidur, kurang nafsu makan, sampai ada yang mengatakan takut melakukan aktifitas di lingkungan sekitar karena takut tertular infeksi virus covid-19. Warga cuman merasa kondisi sekarang yang dialami membuat mereka sulit mendapatkan pekerjaan dan data ini didukung dari hasil penelitian dengan jumlah orang yang tidak bekerja lebih besar dari orang yang bekerja dengan presentasi $(74.8 \%)$.

\section{SIMPULAN}

Terdapat 14 kasus Covid-19 di Kelurahan Peleloan Kecamatan Tondano Selatan Kabupaten Minahasa dan sebagian besar masyarakat tidak mengalami stress, sebagian besar masyarakat tidak mengalami kecemasan, dan sebagian besar masyarakat tidak mengalami depresi. Ketika kasus Covid-19 bertambah banyak akan memungkinkan terjadinya stress, kecemasan dan depresi sehingga implikasinya akan berdampak pada penanganan kesehatan dan keperawatan.

\section{DAFTAR PUSTAKA}

American Psychiatric Association. (2013). Diagnostic and Statistical Manual of Mental Disorder Edition (DSM-V). Washington : American Psychiatric Publishing.

Clement, E. 2019 Gangguan Mental Emosional dan Kesepian pada Mahasiswa Baru, Sumedang. Jurnal

Deshinta, V. 2020. Kesehatan Mental Masyarakat: Mengelola Kecemasan Di Tengah Pandemi Covid-19, Jurnal

Ivan, 2020. Memahami Pandemi COVID19 dalam Perspektif Psikologi Sosial, Jurnal

Huang, L., Zhang, X., Zhang, X., Wei, Z., Zhang, L., Xu, J., Xu, A. (2020). Rapid asymptomatic transmission of COVID-19 during the incubation period demonstrating strong infectivity in a cluster of youngsters aged 16-23 years outside Wuhan and characteristics of young patients with COVID-19: A prospective contacttracing study. Journal of Infection, 80(6), e1-e13. https://doi.org/10.1016/j.jinf.2020.03 .006 
Hawari, 2011. Manajemen Stres Cemas dan Depresi. Jakarta, FKUI

Hawari, D. (2016). Manajemen Stres Cemas dan Depresi. Jakarta: Fakultas Kedokteran Universitas Indonesia.

Joharudin, A, b. dkk., 2020 panic syndrom Covid-19: penekanan terhadap kebijakan yang diberikan pemerintah,

https://www.perspektif.uinsgd.ac.id/i ndex.php/jp/article/view/63/46. Jurnal

Kupferberg, A., Bicks, L., \& Hasler, G. (2016). Social functioning in major depressive disorder. Neuroscience and Biobehavioral Reviews, 69, 313-332.

https://doi.org/10.1016/j.neubiorev.2 $\underline{016.07 .002}$

Kementrian Kesehatan. (2020). Situasi Terkini Perkembangan Coronavirus Disease (COVID-19) 31 Mei 2020. Diambil kembali dari covid19 kemkes.go.id:

https://covid19.kemkes.go.id/situasiinfeksiemerging/info-coronavirus/situasi-terkini-perkembangancoronavirusdisease-Covid-19-31mei-2020/\#.XtRqYb4xWNw

Lilin, R. 2020. Dampak Psikologis dalam Memberikan Perawatan dan Layanan Kesehatan Pasien COVID-19 pada Tenaga Profesional Kesehatan, Jurnal.

Ni Putu, 2020. Gambaran Pengetahuan Masyarakat Tentang Covid-19 Dan Perilaku Masyarakat di masa pandemi Covid-19, Jurnal.

PDSKJI, 2020. Perhimpunan Dokter Spesialis Kedokteran Jiwa Indonesia, http://pdskji.org/home, Di akses tanggal 19 oktober 2020, jam 13.16 Wita.

Perhimpunan Dokter Spesialis Kedokteran Jiwa $\quad 2020$. https://ipkindonesia.or.id/informasiipk-indonesia/2020/09/pernyataanbersama-persatuan-dokter-spesialiskedokteran-jiwa-indonesia-pdskji- dan-ikatan-

HYPERLINK

"https://ipkindonesia.or.id/informasiipk-indonesia/2020/09/pernyataanbersama-persatuan-dokter-spesialiskedokteran-jiwa-indonesia-pdskjidan-ikatan-psikolog-klinisindonesia-ipk-indonesiamemperingati-hari-pencegahanbunuh-diri-sedunia-2020/"psikologklinis-indonesia-ipk-indonesiamemperingati-hari-pencegahanbunuh-diri-sedunia-2020/ Jurnal.

Rina, 2020. Faktor Penyebab Stres Pada Tenaga Kesehatan Dan Masyarakat Saat Pandemi Covid-19, Jurnal.

Sadock ,J.B., \& Sadock, A.V. (2010). Kaplan \& Sadock Buku Ajar Psikiatri Klinis. Edisi ke-2. EGC

Safnal. G, 2017. Kondisi psikologis orang tua yang memiliki anak gangguan jiwa di desa kilangan kecamatan Singkil kabupaten aceh singkil, medan. Skripsi

Satgas Covid-19 RI, 2020. Satuan Penganganan Covid-19 Republik Indonesia, https://covid19.go.id/, Di akses tanggal 20 oktober 2020, jam 08.12 Wita.

Satgas Covid-19 SULUT, 2021. Satuan Gugus Tugas Provinsi Sulawesi Utara, https://corona.sulutprov.go.id/ Di akses tanggal 3 Januari 2021, jam 12.35 Wita.

Sugiyono. 2018. Metode Penelitian Kuantitatif, Kualitatif, dan R\&D. Bandung: Alfabeta.

Saadat, S., Rawtani, D., \& Hussain, C. M. (2020). Environmental perspective of COVID-19. Science of the Total Environment, 728(1), 1-6. https://doi.org/10.1016/j.scitotenv.20 $\underline{20 .}$.

Ummu.A, 2016. Hubungan Antara Kepercayaan Diri Mahasiswa Pada Mahasiswa Psikologi Semester VI Yang Akan Menghadapi Skripsi, Malang. Skripsi

Utami, R. A., Mose, R. E., \& Martini, M. (2020). Pengetahuan, Sikap dan Keterampilan Masyarakat dalam 
Jurnal Keperawatan, Volume 9, No. 2, Agustus 2021, (Hal. 7-15)

Pencegahan COVID-19 di DKI Jakarta. Jurnal Kesehatan Holistic, 4(2), $\quad 68-77$

https://doi.org/10.33377/jkh.v4i2.85

Uswatun, 2020. Depresi Pada Mahasiswa Selama Masa Pandemi Covid-19, Jurnal

Wiwiek, 2020. Gambaran Tingkat Kecemasan Warga Terdampak Covid 19 Di Kecamatan Comal Kabupaten Pemalang, Jurnal'

WHO. (2020). Coronavirus disease (COVID-19) advice for the public: Advocacy. Www.Who.Int. https://www.who.int/emergencies/di seases/novel-coronavirus2019/advice-for-public/healthyparenting, Di akses tanggal 18 oktober 2020, jam 19.00 Wita.

Yanti, B., Wahyudi, E., Wahiduddin, W., Novika, R. G. H., Arina, Y. M. D., Martani, N. S., \& Nawan, N. (2020). Community Knowledge, Attitudes, and Behavior Towards Social Distancing Policy As Prevention Transmission of Covid-19 in Indonesia. JurnalAdministrasi Kesehatan Indonesia, 8(2), 4. https://doi.org/10.20473/jaki.v8i2.20 20. 4-1 